\title{
Introduction
}

\section{Larry O'Farrell}

Holder of the UNESCO Chair in Arts and Learning, Queen's University

He PAPERS PRESENTED IN THIS ISSUE OF Encounters on Education were writ-
ten to reflect current developments in arts and learning in the context of the UNESCO Road Map for Arts Education. ${ }^{1}$ The Road Map was a key outcome of the first UNESCO World Conference on Arts Education held in Lisbon, Portugal in 2006. An important theoretical and practical framework that offered guidance for advancing the qualitative development and growth of arts education, the Road Map laid out a set of priorities in research, best practice, policy development, networking, and the training of teachers and artists with reference to learning both in schools and in community arts programs. These papers address a variety of issues related to the themes of the Road Map.

Coincidental with the preparation of this issue, UNESCO in partnership with the Republic of Korea, held a second World Conference on Arts Education (Seoul, 25-28 May, 2010). This second conference aimed to assess the impact of the Road Map and to extend its influence. A central outcome of the event was a concrete plan of action that integrates the substance of the Road Map within a structure of three broad goals each of which is accompanied by a number of practical strategies and specific action items. The plan of action has been entitled The Seoul Agenda: Goals for the development of arts education. ${ }^{2}$

In view of the intent of the Seoul Agenda to extend and promote the Road Map, this issue has been organized according to the three goals articulated in the Seoul Agenda. Each of the goals is addressed by papers which are associated with specific strategies supporting the relevant goal. Written by contributors in Australia, Canada, New Zealand, Spain, the United Kingdom, and United States this issue offers a wide range of international perspectives.

\section{Goal 1: Ensure that arts education is accessible as a fundamental and sustainable component of a high quality renewal of education}

One of the action items identified in support of this goal is to "establish high quality evaluation systems in order to ensure the well-rounded development of learners in arts education." (1.a iii) Christopher DeLuca's article on "The Capacity of Assessment in Arts Education" addresses this item directly. Noting a lack of research in the area, he argues that it is necessary to find "ways to effectively assess artistic learning that work within the existing accountability parameters" in order to enhance the position of arts within the curriculum.

Another action advocated under this same goal is to "apply arts education to 
introduce innovative pedagogies and creative approaches to curricula that will engage a diversity of learners." (1.b iii) The paper by Kathryn Grushka on "Conceptualising Visual Learning as an Embodied and Performative Pedagogy for all Classrooms" describes research that is consistent with this item. Grushka explains that "the visual has significant potential as a conduit for knowledge acquisition and meaning making in the digital environment."

Ana Mampaso's article on “'La Fortuna, por siempre y para siempre,' a crossgenerational and participatory documentary" speaks to UNESCO's call to "facilitate intergenerational learning." (1.c iii) She reflects on participatory video methodology and describes a project in which 28 children, 6 youngsters and 9 adults collaborated on the creation of a documentary video about living together in a multi-ethnic neighborhood.

Kathleen Gallagher's contribution, "Off the Beaten Track: A reflection on intention and unpredictability in arts education research" addresses the Seoul Agenda's commitment to "building practitioners' and researchers' capacities for arts education policy reform." (1.d i) While noting that a road map can be a useful starting point, Gallagher advises researchers to be on the lookout for the unexpected, particularly in those arts experiences that cannot be easily calibrated and measured.

\section{Goal 2: Assure that arts education activities and programmes are of a high quality in conception and delivery}

Anne Bamford speaks to the Seoul Agenda's proposal to "establish high standards for arts education that are responsive to local needs, infrastructure, and cultural contexts," (2.a i \& ii) arguing that quality is largely neglected in discussions about arts education, to the detriment of the field. Her thesis is that quality assurance can be an ally of arts education and that evaluation should be conducted with local conditions in mind.

Janinka Greenwood is concerned about moving from the acceptance of arts in the school curriculum to high quality delivery by teachers. Her paper, "Road Blocks, Road Works and Continuing Explorations of the Terrain: An examination of drama in education in New Zealand in relation to the UNESCO Road Map" argues that "in surface terms at least, drama in New Zealand has come a long way in travelling along the routes indicated by the UNECSO Road Map." At the same time, she recognizes that she and her colleagues are still in the early stages of exploring what they can do with the art form.

B.W. Andrews contributes to the discussion on quality in his paper, "Seeking Harmony: Teachers' perspectives on learning in and through the Arts" which relates to the Seoul Agenda's aspiration to "offer necessary skills and knowledge for teachers. . . through sustainable professional learning mechanisms.” (2.b i) His research found that "when artists are involved in professional upgrading, teachers acquire the confidence to express themselves freely, they are willing to teach the arts in their own classrooms, they realize the potential and value of the arts within the school curriculum, and they develop arts-specific teaching expertise." 
The Seoul Agenda seeks to "encourage schools to initiate partnerships between artists and teachers in delivering curricula." (2.d i) Writing about the effect of artists in the schools and the participation of pupils, Myriam Lemonchois argues that the artist has the capacity to "help the pupils formulate an artistic intention and put it to the test."

\section{Goal 3: Apply the principles and practices of arts education to contribute to resolving the social and cultural challenges facing the world today}

An important element of the Seoul Agenda, is its commitment to applying arts education to the resolution of social and cultural challenges. One specific application proposed is the cultivation of a new generation of creative citizens through arts education. (3.a i) Elizabeth Garber explores this issue in her article "Global and Local: Rethinking citizenship in art and visual culture education." She provides examples from her own teaching that illustrate strategies she has used to engage future art and visual culture educators in an understanding of the goals and principles of democratic education.

The Seoul Agenda aims to apply arts education to reduce education dropout levels (3.b iii), a point addressed by Debra McLauchlan in her article "Keeping the Kids in School: What the drama class tells us." In a qualitative study, she learned that secondary school students valued the opportunities provided in drama for personal and social growth with the result that, "In such environments, students felt motivated to attend class, achieve high expectations, and invest emotionally in their schoolwork."

In her paper on "Musically Creolizing Subjects: Re(envisioning) world music education," Juliet Hess provides personal insight into issues associated with UNESCO's plan to "Introduce intercultural dialogue skills, pedagogy, equipment and teaching materials in support of training programmes in arts education." (3.c iii) She proposes that, despite the risks of self-congratulation and essentializing people of other cultures, the critical and mindful inclusion of world music in a music education program can provide an opportunity for participants to become creolized subjects and to transcend borders.

\section{Notes}

1. UNESCO. (2006). The UNESCO Road Map for Arts Education. [On-line], Available: http://portal.unesco.org/culture/en/ev.php-URL_ID=30335\&URL_DO=DO_ TOPIC\&URL_SECTION=201.html

2. UNESCO. (2010). The Seoul Agenda: Goals for the development of arts education. [On-line], Available: http://www.unesco.org/culture/en/artseducation 